\title{
REVIEW
}

\section{The year in cardiology 2019: valvular heart disease}

\author{
Ronald K. Binder', Marc Dweck², and Bernard Prendergast ${ }^{3}$
}

\section{PREAMBLE}

After decades as a Cinderella discipline, valvular heart disease (VHD) now occupies the centre stage of cardiovascular medicine. Changing societal demographics and an ageing population (with increasing prevalence of degenerative disease), advances in imaging and the explosion of interest in transcatheter interventional techniques (supported by a series of landmark clinical trials) have attracted clinicians, researchers, engineers, device manufacturers and investors, and transformed the landscape of clinical management. In many senses, 2019 has been a leap year for VHD.

\section{EPIDEMIOLOGICAL TRENDS}

The changing demography of VHD and its impact on clinical management were highlighted by the EURObservational Research Programme VHD II Survey,' a contemporary registry of 7247 patients (4483 hospitalized, 2764 outpatients) with VHD treated at 222 centres in 28 nations. Key findings included the rising age of patients with VHD in comparison with a similar survey performed in $2005,{ }^{2}$ a high concordance with guideline recommendations for patients with aortic valve disease (though less so for mitral valve disease where referral for intervention was frequently delayed), and the progressive emergence of transcatheter interventions (aortic stenosis 39\%, mitral regurgitation $17 \%)$.

\footnotetext{
' Department of Cardiology and Intensive Care, Klinikum Wels, Wels, Austria

${ }^{2}$ Centre for Cardiovascular Science, University of Edinburgh, Edinburgh, UK

${ }^{3}$ Department of Cardiology, St Thomas' Hospital and Cleveland Clinic, London, UK
}

\section{DIAGNOSTIC IMAGING}

Multimodality imaging is of fundamental importance in VHD for initial diagnosis, monitoring of disease progression (valve lesion and associated myocardial remodelling response), planning of transcatheter and surgical intervention, and subsequent follow-up.

\section{The valve}

Echocardiography remains the first-line imaging modality in VHD. An investigation of inter-observer reproducibility of peak velocity and mean gradient measurements in patients with aortic stenosis (based on 20 echocardiographic examinations assessed by 25 different observers) demonstrated superior reproducibility of peak velocity compared with mean gradient assessment (coefficient of variation 10.1 vs. $18.0 \%$; $P$ $<0.00 \mathrm{I}$ ), suggesting that peak velocity should be the preferred measure for tracking the progression of aortic stenosis. ${ }^{3}$ Asymptomatic patients with a peak velocity $>5 \mathrm{~m} / \mathrm{s}$ and ejection fraction $<60 \%$ have increased mortality [even after aortic valve replacement (AVR)] and early intervention should be considered in these high-risk patients. ${ }^{4}$

European Society of Cardiology (ESC) guidelines recommend computed tomography (CT) calcium scoring to assess the severity of aortic stenosis when echocardiographic measurements are discordant. ${ }^{5}$ Advances in this field include clear guidance on optimal scoring of valve calcification ${ }^{6}$ and a large internati-

\footnotetext{
$\checkmark$ Contact address:

Bernard Prendergast

Department of Cardiology, St Thomas' Hospital and Cleveland Clinic, London, UK

E-mail: bernard.prendergast@gstt.nhs.uk

Tel: +442071887188

Copyright:

Ronald K Binder, Marc Dweck, Bernard Prendergast, The year in cardiology: valvular heart disease: The year in cardiology 2019,

European Heart Journal, Volume 4I, Issue 8, 2I February 2020, Pages

912-920,https://doi.org//0.1093/eurheartj/ehz948

Published on behalf of the European Society of Cardiology. All rights reserved.

For permissions, please email: journals.permissions@oup.com
} 

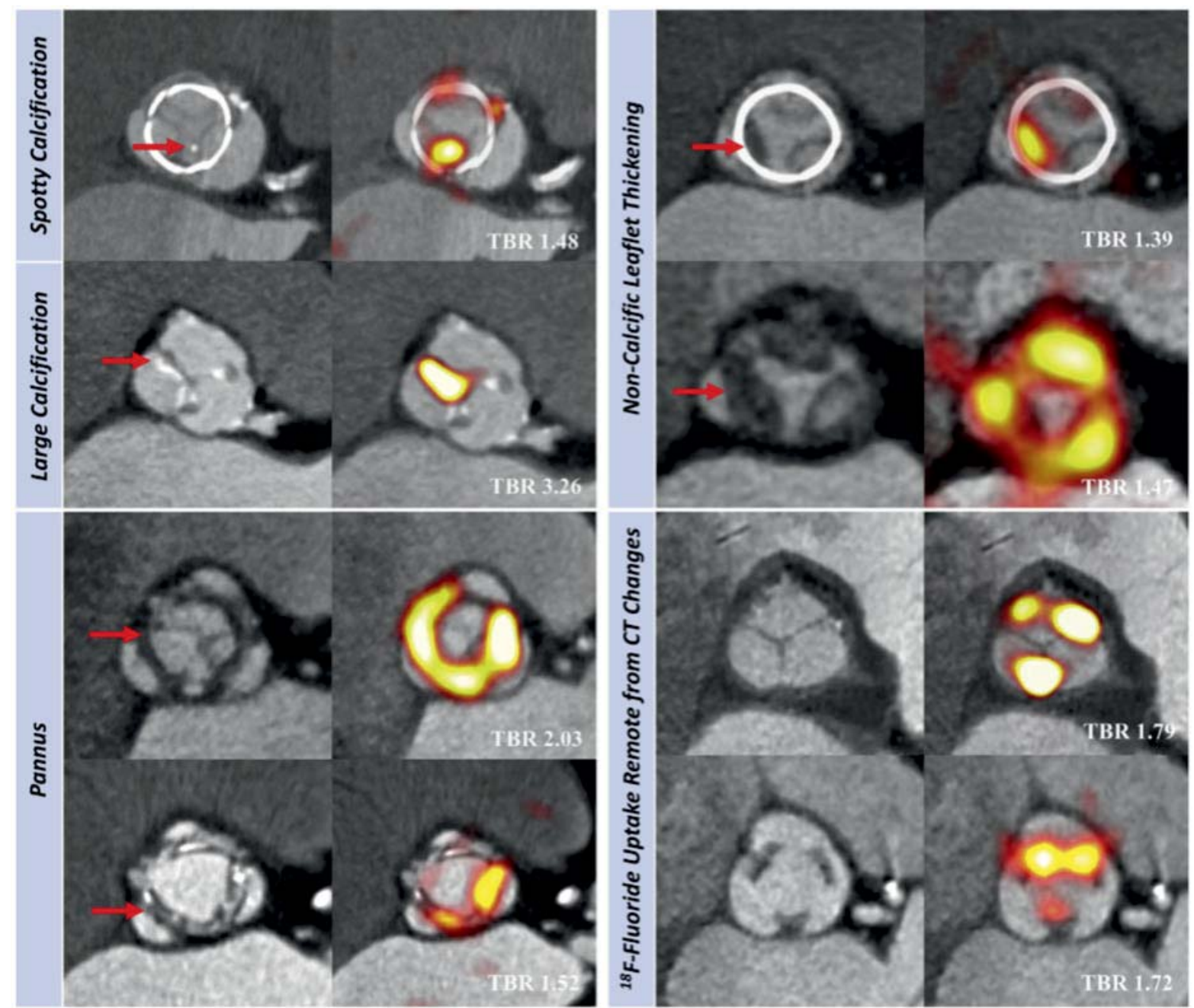

Figure I. In vivo ${ }^{18} \mathrm{~F}$-fluoride positron emission tomography and computed tomography imaging of patients with bioprosthetic aortic valves. Baseline computed tomography (left) and ${ }^{18} \mathrm{~F}$-fluoride positron emission tomography (right) images from patients with bioprosthetic aortic valves. En-face computed tomography images of bioprosthetic aortic valves showing spotty and large calcification (top left), circumferential pannus (bottom left), and non-calcific leaflet thickening suggestive of thrombus (top right) (all identified by red arrows). Hybrid en-face positron emission tomography- computed tomography images in the same patients: increased bioprosthetic ${ }^{18} \mathrm{~F}$-fluoride activity (red/yellow) colocalize with computed tomography abnormalities in each patient. ${ }^{18} \mathrm{~F}$-fluoride activity was also commonly observed remote from leaflet changes on computed tomography (bottom right). Target-to-background values are annotated on the hybrid positron emission tomography-computed tomography images (white text). Reproduced with permission from ref. ${ }^{8}$

onal multicentre study confirming the diagnostic accuracy of this method and its power to predict disease progression and clinical events. ${ }^{7}$

Positron emission tomography (PET) imaging using I8F-fluoride as a marker of calcification activity may detect early bioprosthetic valve degeneration before it is evident on echocardiography or CT (Figure I). Indeed, one study demonstrated histological validation of increased tracer uptake by bioprosthetic leaflets as a marker of degeneration and the only independent predictor or future valve dysfunction. ${ }^{8}$ However, the potential for integration of these findings into clinical practice remains uncertain.

\section{The myocardium}

Myocardial damage secondary to VHD is being increasingly investigated using novel echocardiographic and cardiovascular magnetic resonance (CMR) approaches. In primary mitral regurgitation (MR), for example, myocardial fibrosis identified on CMR is closely associated with increased incidence of ventricular arrhythmias, ${ }^{9}$ whilst impaired echocardiographic global longitudinal strain (threshold $>_{-}$20.6\%) is associated with adverse long-term prognosis in subjects undergoing surgery. ${ }^{10}$

Left ventricular mechanical dispersion assessed using speckle tracking echocardiography demonstra- 


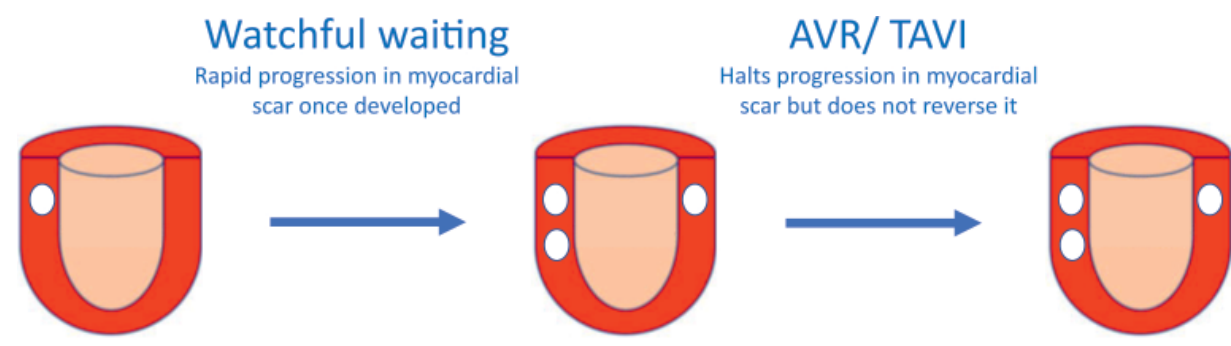

Myocardial scar that patients develop whilst waiting for AVR persists for life and is associated with adverse prognosis

$$
\left.\begin{array}{c}
\text { Myacardial } \\
\text { scar }
\end{array}\right)=\begin{aligned}
& \uparrow \text { Mortality } \\
& \uparrow \text { Hospital Admissions }
\end{aligned}
$$

Figure 2. Myocardial scar in aortic stenosis. Cardiovascular magnetic resonance late gadolinium enhancement allows detection of non-infarct pattern replacement fibrosis (white areas) in patients with severe aortic stenosis. This myocardial scar is associated with multiple markers of left ventricular decompensation and progresses rapidly until aortic valve replacement or transcatheter aortic valve implantation is performed.Although these interventions halt the development of further scar, replacement fibrosis that develops whilst awaiting intervention is irreversible, persists lifelong and is associated with dose-dependent impact on long-term prognosis.

ted incremental prognostic value for all-cause mortality in 630 patients with aortic stenosis [hazard ratio (HR) I.I 0 (95\% confidence interval, Cl I.04-I.I5) per 10 ms increase; $P<0.001]$." Similarly, reduced endocardial, mid-myocardial, and epicardial longitudinal strain predicted symptomatic status in 211 patients with severe aortic stenosis, whilst endocardial longitudinal strain provided an independent predictor of cardiovascular mortality. ${ }^{12}$ Extending this concept, a four-stage system for the echocardiographic grading of cardiac damage in 735 patients with asymptomatic moderate or severe aortic stenosis provided incremental prognostic information over and above standard clinical variables. ${ }^{13}$

Myocardial fibrosis is the major driver of left ventricular decompensation in aortic stenosis and may be directly visualized using CMR. ${ }^{14}$ Replacement fibrosis progresses rapidly once established, persists following valve replacement, and is associated with poor longterm prognosis (Figure 2). ${ }^{15,16}$ The ongoing EVOLVED trial (NCT03094I43) will determine whether prompt AVR/transcatheter aortic valve implantation (TAVI) can improve clinical outcomes in asymptomatic patients with severe aortic stenosis and evidence of early fibrosis.

\section{DEVELOPING MEDICAL THERAPIES}

Unlike other major cardiovascular conditions, effective medical therapies are lacking for VHD. Intense re- search has focused upon identifying novel therapeutic targets, particularly in aortic stenosis. Amongst 367 703 UK BIOBANK participants, obesity was associated with increased risk of aortic stenosis, thereby underlining the potential importance of weight reduction as a preventive strategy. ${ }^{17}$

Preclinical studies have highlighted the role of platelet activation in the progression of aortic stenosis, ${ }^{18}$ whilst $L_{p}(a)$ is associated with increased aortic valve calcification, faster progression of aortic stenosis, and increased risk of intervention or death, ${ }^{19}$ and provides an extremely promising therapeutic target. Statins increase $L_{p}(\mathrm{a})$ however, ${ }^{20}$ and tailored treatment may prove necessary.

Calcification is the major driver of progressive aortic stenosis and the target of novel imaging technologies and potential therapeutic strategies, including the on-going SALTIRE II (NCT02 I32026) and BASIK II (NCT02917525) randomized controlled trials. ${ }^{21}$ A Swedish population study of over I million subjects confirmed the association between aortic stenosis and chronic kidney disease, presumably related to altered calcium and phosphate metabolism, ${ }^{22}$ whilst a nonrandomized study of 2785 patients demonstrated greater reduction in left ventricular volumes, hypertrophy, and cardiovascular mortality associated with the use of renin-angiotensin system inhibitors following TAVI. ${ }^{23}$ Randomized controlled trials are now required. 


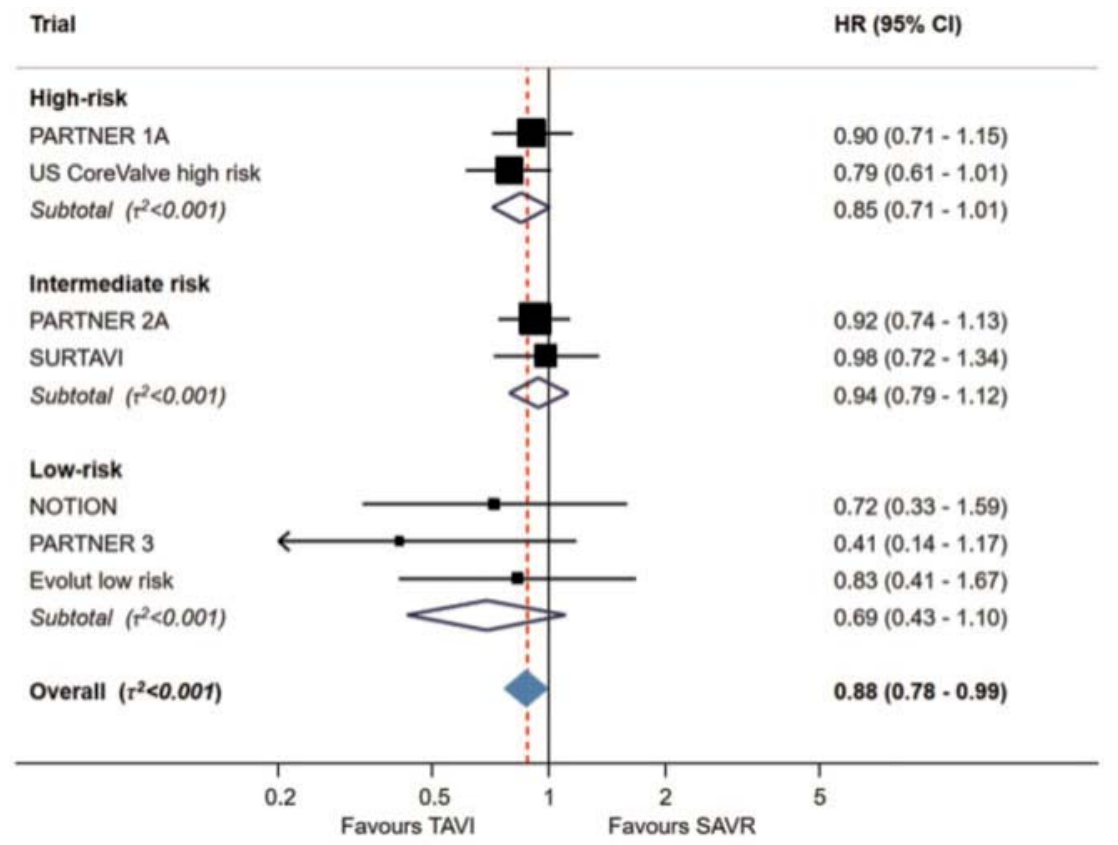

Figure 2. Myocardial scar in aortic stenosis. Cardiovascular magnetic resonance late gadolinium enhancement allows detection of non-infarct pattern replacement fibrosis (white areas) in patients with severe aortic stenosis. This myocardial scar is associated with multiple markers of left ventricular decompensation and progresses rapidly until aortic valve replacement or transcatheter aortic valve implantation is performed. Although these interventions halt the development of further scar, replacement fibrosis that develops whilst awaiting intervention is irreversible, persists lifelong and is associated with dose-dependent impact on long-term prognosis.

\section{TRANSCATHETER INTERVENTION}

\section{The aortic valve}

Transcatheter aortic valve implantation in low surgical risk patients

In 2019, an important evidence gap for TAVI was closed following publication of two landmark trials 24,25 comparing TAVI and surgical aortic valve replacement (SAVR) in patients at low surgical risk.

In the PARTNER 3 trial, ${ }^{24} 1000$ patients with symptomatic severe aortic stenosis at low surgical risk were randomly assigned to undergo SAVR or TAVI with the balloon-expandable Edwards SAPIEN 3 transcatheter heart valve (THV). Those with a bicuspid valve or highrisk anatomical features for either procedure were excluded. The primary endpoint (a composite of death, stroke, or rehospitalization) was tested for non-inferiority as well as superiority in the as-treated population. At I year, the primary endpoint was significantly lower in the TAVI group than in the SAVR group ( $8.5 \%$ vs. $15.1 \%, P<0.00$ I for non-inferiority; HR $0.54,95 \% \mathrm{Cl} 0.37-0.79 ; \mathrm{P}=0.00$ I for superiority), principally driven by reduced rates of rehospitalization. There were no significant differences in major vascular complications, need for new permanent pacemaker implantation, or more than mild paravalvular regurgitation.
Similarly, in the Evolut Low Risk Trial, ${ }^{25}$ I 468 patients with symptomatic severe aortic stenosis at low surgical risk were randomly assigned to undergo SAVR or TAVI with the self-expanding CoreValve, Evolut-R, or Evolut Pro THV (Medtronic, USA). At 24 months, the estimated incidence of the primary endpoint (a composite of death or disabling stroke) was $5.3 \%$ in the TAVI group and $6.7 \%$ in the SAVR group [difference $-1.4 \%$; $95 \%$ Bayesian credible interval for difference $(\mathrm{BCl})-4.9$ to 2.1 ; posterior probability of noninferiority $>0.999]$. At 30 days, TAVI patients had lower incidence of disabling stroke $(0.5 \%$ vs. $1.7 \% ; 95 \% \mathrm{BCl}$ -2.4 to -0.2$)$, acute kidney injury $(0.9 \%$ vs. $2.8 \%$; $95 \%$ $\mathrm{BCl}-3.4$ to -0.5$)$, and atrial fibrillation $(7.7 \%$ vs. $35.4 \%$; $95 \% \mathrm{BCl}-31.8$ to -23.6$)$ but higher incidence of moderate or severe aortic regurgitation $(3.5 \%$ vs. $0.5 \%$; $\mathrm{P}<0.05)$ and pacemaker implantation ( $17.4 \%$ vs. $6.1 \%$; 95\% BCl 8.0-14.7).

Alongside previous landmark studies, these results complete the evidence trail comparing TAVI and SAVR in all surgical risk categories and establish TAVI as a treatment for severe aortic stenosis irrespective of surgical risk. Furthermore, meta-analysis of the 8020 patients enrolled in the seven randomized trials across the entire spectrum of surgical risk demonstrated a significant reduction of I-year all-cause mortality with 


\begin{tabular}{|c|c|c|c|}
\hline & Primary endpoint & $\begin{array}{l}\text { MITRA-FR } \\
\text { All-cause death and } \\
\text { hospitalization for CHF at } \\
\text { I year }\end{array}$ & $\begin{array}{l}\text { COAPT } \\
\text { All hospitalizations for CHF } \\
\text { within } 2 \text { years (including } \\
\text { recurrent events) }\end{array}$ \\
\hline Key exclusion criteria & $\begin{array}{l}\text { Heart failure severity } \\
\text { Left ventricular dimensions } \\
\text { Coronary artery disease } \\
\text { Right ventricle } \\
\text { Pulmonary disease }\end{array}$ & $\begin{array}{l}\text { NYHA class < II } \\
\text { No exclusion criteria } \\
\text { CABG or PCl performed within I } \\
\text { month } \\
\text { No exclusion criteria } \\
\text { No exclusion criteria }\end{array}$ & $\begin{array}{l}\text { NYHA class < II ACC/AHA stage D } \\
\text { heart failure } \\
\text { LVESD }>70 \mathrm{~mm} \\
\text { Untreated coronary artery disease } \\
\text { requiring revascularization } \\
\text { Right-sided congestive heart failure } \\
\text { with moderate or severe right } \\
\text { ventricular dysfunction } \\
\text { COPD with home oxygen therapy or } \\
\text { chronic oral steroid use } \\
\text { Estimated or measured PAP }>70 \\
\mathrm{mmHg}\end{array}$ \\
\hline $\begin{array}{l}\text { Principal baseline } \\
\text { characteristics }\end{array}$ & $\begin{array}{l}\text { Number of patients screened } \\
\text { Number of patients enrolled (ITT) } \\
\text { Mean age (years) } \\
\text { Mean LVEF (\%) } \\
\left.\text { MR severity (EROA, } \mathrm{cm}^{2}\right) \\
\text { Mean indexed LVEDV }\left(\mathrm{mL} / \mathrm{m}^{2}\right) \\
\end{array}$ & \begin{tabular}{|l|}
450 \\
304 \\
$70 \pm 10$ \\
$33 \pm 7$ \\
$0.31 \pm 0.10$ \\
$135 \pm 35$ \\
\end{tabular} & \begin{tabular}{|l|}
1576 \\
614 \\
$72 \pm 12$ \\
$31 \pm 10$ \\
$0.41 \pm 0.15$ \\
$101 \pm 34$ \\
\end{tabular} \\
\hline $\begin{array}{l}\text { Safety and efficacy endpoints in } \\
\text { the intervention arm }\end{array}$ & $\begin{array}{l}\text { Complications }^{\mathrm{a}}(\%) \\
\text { No implant }(\%) \\
\text { Implantation of multiple clips (\%) } \\
\text { Post-procedural MR grade } \leq 2+(\%)^{\mathrm{b}} \\
\text { MR grade } \leq 2+\text { at I year }(\%)^{\mathrm{b}} \\
\text { Hospitalization for CHF at I year (\%) } \\
\text { 30-day mortality (\%) } \\
\text { I-year mortality (\%) }\end{array}$ & $\begin{array}{l}14.6 \\
9 \\
54 \\
92 \\
83 \\
49 \\
3.3 \\
24\end{array}$ & $\begin{array}{l}8.5 \\
5 \\
62 \\
95 \\
95 \\
38 \\
2.3 \\
19\end{array}$ \\
\hline \multicolumn{4}{|c|}{$\begin{array}{l}\text { ACC, American College of Cardiology; AHA, American Heart Association; BNP, brain natriuretic peptide; CHF, congestive heart failure; COPD, chronic obstructive pulmonary disease; EROA, effec- } \\
\text { tive regurgitant orifice area; ITT, intention to treat; LVEF, left ventricular ejection fraction; LVESD, left ventricular end-systolic diameter; MR, mitral regurgitation; NT-proBNP, N-terminal pro brain } \\
\text { natriuretic peptide; PAP, pulmonary artery pressure. } \\
\text { a MITRA-FR definition of pre-specified serious adverse events: device implant failure, transfusion or vascular complication requiring surgery, ASD, cardiogenic shock, cardiac embolism/ } \\
\text { stroke, tamponade, urgent cardiac surgery. } \\
\text { b According to ESC/EACTS guidelines5 in MITRA-FR and AHA/ACC Guidelines }{ }^{43} \text { in COAPT. }\end{array}$} \\
\hline
\end{tabular}

TAVI compared to SAVR (HR 0.88, 95\% Cl 0.78-0.99, $\mathrm{P}=0.03)$ and lower risk of stroke $(\mathrm{HR} 0.8 \mathrm{I}, 95 \% \mathrm{Cl}$ $0.68-0.98, P=0.03$; Figure 3$).{ }^{26}$ These results have already translated into routine clinical practice in several European nations, as demonstrated by analysis of the German national aortic valve replacement registry (GARY). ${ }^{27}$ Comparison of 14487 SAVR patients and 6062 TAVI patients at low surgical risk demonstrated superior in-hospital and 30-day survival for TAVI compared to SAVR (98.5\% vs. $97.3 \%, P=0.003 ; 98.1 \%$ vs. $97.1 \%, P=0.014$; respectively) with equivalent survival at I year $(90.0 \%$ vs. $91.2 \%, P=0.16)$.

These favourable outcomes of TAVI indicate that surgical risk estimation is no longer the basis to guide the choice between TAVI and SAVR. Heart Teams should now weigh clinical and anatomic characteristics to identify the best treatment option for individual patients with transfemoral TAVI replacing SAVR as the default therapy for symptomatic severe aortic stenosis. Future research will need to address remaining uncertainties and options for further improvement in outcomes, including evaluation of TAVI in younger and asymptomatic patients (patients enrolled in the low-risk trials summarized above had a mean age of 74 years), assessment of THV durability using predefined clinical and echocardiographic assessment (5-year follow-up in the major randomized controlled trials has already demonstrated low rates of structural valve deterioration compared with SAVR but longer-term data and larger patient numbers remain essential), ${ }^{28-31}$ more detailed evaluation of TAVI in patients with bicuspid aortic valve disease and concomitant coronary artery disease, continued measures to reduce the need for permanent pacemaker implantation, definition of the optimal short- and long-term regimes of antithrombotic therapy, and the institutional and operator standards required to achieve clinical outcomes that match those in the randomized controlled trials. ${ }^{32}$

\section{Stroke and transcatheter aortic valve implantation}

Stroke is a rare but potentially devastating complication of TAVI that impacts quality of life, independent li- 


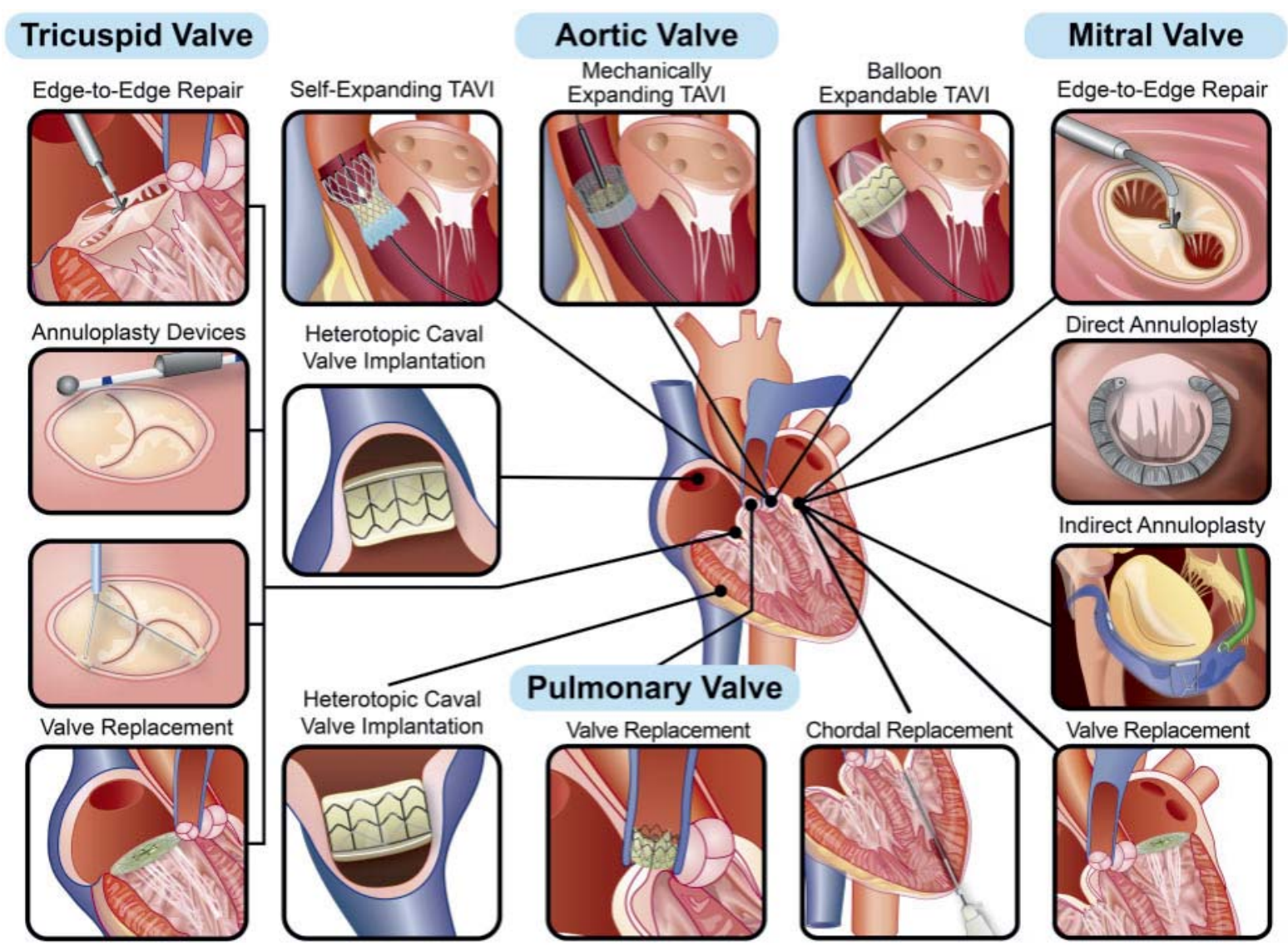

Take home figure. The scope of transcatheter intervention for valvular heart disease in 2019.

ving and survival. Cerebral protection devices (CPDs) are intended to reduce the risk of cerebral embolism by capturing or deflecting debris during the TAVI procedure. A patient-level propensity-matched analysis ${ }^{33}$ of the SENTINEL US IDE trial, ${ }^{34}$ the CLEAN-TAVI trial, ${ }^{35}$ and the SENTINEL-Ulm study ${ }^{36}$ showed that TAVI with a dual-filter CPD (Claret Medical Inc., CA, USA) was associated with a significantly lower rate of procedural stroke compared with unprotected procedures (I.9\% vs. $5.4 \%$, odds ratio $0.35,95 \% \mathrm{Cl} 0.17-0.72$, relative risk reduction $65 \%, P=0.0028)$. However, this pooled analysis contained data from a nonrandomized study ${ }^{36}$ and significant reduction in stroke with the use of CPD has yet to be shown in a major randomized trial.

Comparison of different transcatheter aortic valve implantation devices

Data directly comparing different TAVI devices are scarce. In the SCOPE I trial, ${ }^{37}$ the self-expanding Symetis ACURATE Neo valve (Boston Scientific, USA) was randomly compared to the SAPIEN 3 balloonexpandable valve (Edwards Lifesciences, CA, USA) in
739 patients. The primary endpoint (all-cause mortality, any stroke, lifethreatening or disabling bleeding, major vascular complications, coronary obstruction requiring intervention, acute kidney injury, rehospitalization for valve-related symptoms or congestive heart failure (HF), valve-related dysfunction requiring repeat procedure, moderate or severe prosthetic valve regurgitation, or prosthetic valve stenosis within 30 days of the procedure) occurred in $87(24 \%)$ and 60 (16\%) of patients in the ACURATE Neo and SAPIEN 3 groups, respectively. Non-inferiority criteria for the ACURATE Neo were not met [absolute risk difference $7.1 \%$ (upper $95 \% \mathrm{Cl} 12.0 \%$ ), $\mathrm{P}=0.42$ ], and secondary analysis demonstrated that superiority of the SAPIEN 3 THV ( $95 \% \mathrm{Cl}$ for risk-difference, - I. 3 to $-12.9 \% ; P=0.016)$ was driven by lower rates of acute kidney injury [3 $(0.8 \%)$ vs. II (3\%)] and moderate or severe prosthetic aortic regurgitation [10 (2.8\%) vs. 34 (9.4\%)]. Outcomes of the SCOPE II trial, comparing the selfexpanding Evolut (Medtronic, USA) and balloon-expandable SAPIEN 3 (Edwards Lifesciences, CA, USA) THVs in similar fashion are keenly awaited. 
Valve-in-valve transcatheter aortic valve implantation in small surgical bioprostheses

Valve-in-valve TAVI in small surgical bioprostheses can result in high residual gradients that are associated with increased morbidity and mortality, and bioprosthetic valve fracture (BVF) improves residual gradients in this setting. In a multicentre registry of 75 patients, ${ }^{38}$ BVF led to a final mean transvalvular gradient of $9.2 \pm$ $6.3 \mathrm{mmHg}$, with superior haemodynamic outcomes when BVF was performed immediately after (rather than before) THV implantation $(8.1 \pm 4.8 \mathrm{mmHg}$ vs. $16.9 \pm 10.1 \mathrm{mmHg}$; $\mathrm{P} 0.00 \mathrm{I}$ ). No aortic root disruptions or coronary occlusions were observed. This emerging concept and the associated BASILICA technique $^{39}$ (electrocautery-induced laceration of the bioprosthetic valve leaflets in patients at high risk of coronary obstruction) require comparison with re-do surgery in patients with structural valve deterioration affecting small surgical bioprostheses.

\section{The mitral valve}

The conflicting results of the COAPT ${ }^{40}$ and MITRA$\mathrm{FR}^{41}$ randomized controlled trials evaluating the safety and efficacy of transcatheter edge-to-edge repair using the MitraClip device in patients with symptomatic HF and moderate-severe secondary mitral regurgitation MR despite medical therapy generated considerable discussion, with almost 20 editorial articles attempting to address subtle differences between the studies (Table I) and their implementation in clinical practice. ${ }^{42}$ Meanwhile, extended observations from both studies showed no change in the findings of MITRAFR, with no impact of MitraClip implantation on allcause mortality or HF hospitalization at 24-month follow-up, ${ }^{44}$ whilst the benefits of MitraClip implantation in COAPT were even more pronounced at 3-year follow-up [composite endpoint of death and HF rehospitalization $58.8 \%$ vs. $88.1 \%$, HR 0.48 (95\% $\mathrm{Cl}$ 0.39-0.59), $\mathrm{P}<0.00 \mathrm{I}$; number need to treat 3.4 (95\% Cl 2.7-4.6)]. ${ }^{45}$ A proposed pathophysiological model of 'proportionate' and 'disproportionate' $M R^{46}$ based upon the relationship between left ventricular end-diastolic volume and effective regurgitant orifice area, and its disruption in patients with ventricular dyssynchrony or papillary muscle dysfunction, may explain these disparities and awaits prospective validation. Cost-effectiveness analysis of COAPT at 2 years confirmed a higher cost of intervention overall ( $\$ 73$ 416 vs. $\$ 38345, P<0.00$ I; predominantly related to the price of the MitraClip device) but acceptable economic value based upon current US thresholds (incre- mental cost-effectiveness ratio $\$ 4036$ I per life-year gained, $\$ 55600$ per quality-adjusted life-year gained). ${ }^{47}$

Although large-scale clinical experience $(>100000$ patients) and outcome data are only available for MitraClip edge-to-edge repair, the Carillon Mitral Contour system (Cardiac Dimensions, Kirkland, WA, USA) was also investigated in a randomized sham-controlled study (REDUCE-FMR) amongst patients receiving guideline-directed medical therapy. ${ }^{48}$ At 12 months, indirect annuloplasty using this system was associated with a significant fall in MR regurgitant volume (the primary endpoint) accompanied by reduction in left ventricular volumes and improvement in paired 6-min walking distance and New York Heart Association (NYHA) functional class. However, the trial was not powered for clinical endpoints and the reported reduction in MR regurgitant volume $(22 \%)$ was modest compared to that typically achieved following MitraClip edge-to-edge repair (60-70\%). ${ }^{49}$

Meanwhile, the evidence supporting surgical intervention for secondary mitral regurgitation remains weak. Mitral annuloplasty, the most commonly used technique for surgical mitral valve repair, reduces $M R$, improves symptoms and results in reverse left ventricular remodelling in the short term. However, it remains unclear whether these outcomes are durable or reduce mortality although low rates of recurrent MR (28\%) were recently reported at I0-year followup in a single-centre study. ${ }^{50}$ Further high-quality studies will be required to refine selection criteria for the various medical and interventional treatment options in this high-risk group, explore indications for MitraClip beyond the current evidence base, and investigate the role of other transcatheter devices (annuloplasty, combined repair techniques, valve replacement).

\section{The tricuspid valve}

Transcatheter strategies for tricuspid disease remain in their early stages. Anatomical challenges include the large annulus, paucity of valve/annular calcification, adjacency of the right coronary artery, and fragility of the valve tissue. Current approaches under investigation in feasibility and early phase clinical trials include edge-to-edge repair, coaptation enhancement, annuloplasty, heterotopic caval valve implantation, and percutaneous tricuspid valve replacement. ${ }^{51}$ The supporting dataset is substantially smaller than for mitral interventions (which is itself limited) although promising early outcomes have been demonstrated with the MitraClip device. ${ }^{52,53}$ Although recent studies have suggested potential advantages of transcatheter 
intervention compared with medical therapy, ${ }^{54}$ major questions that need to be addressed by future trials include whether earlier intervention for tricuspid regurgitation may be beneficial, and whether combined mitral and tricuspid procedures improve procedural success and clinical outcomes.

\section{The pulmonary valve}

Twenty years since the first-in-human procedure, transcatheter pulmonary valve implantation (TPVI) has become the gold standard for treatment of pulmonary conduit dysfunction. In a retrospectivemulticentre analysis of 845 patients undergoing TPVI with the MelodyTM valve (Medtronic, USA), ${ }^{55}$ the composite endpoint of TPVI-related events (death, reoperation, or reintervention $>48 \mathrm{~h}$ after TPVI) occurred with an incidence of $4.2 \%$ per person per year $(95 \% \mathrm{Cl} 3.7-$ 4.9) confirming procedural efficacy in a large cohort of congenital heart disease patients. Long-term risk of infective endocarditis is a concern in this setting and preventivemeasures are essential. ${ }^{56}$

\section{INFECTIVE ENDOCARDITIS}

The prospective EURO-ENDO registry of 3116 adult patients ( 156 hospitals, 40 countries) with infective endocarditis confirmed persistent adverse outcomes (in-hospital mortality 17\%, embolic complications $21 \%)$ despite advances in imaging, antibiotic therapy, and earlier surgery. ${ }^{57}$ Predictors of mortality included Charlson index, creatinine $>2 \mathrm{mg} / \mathrm{dL}$, congestive HF, vegetation length $>10 \mathrm{~mm}$, presence of abscess or cerebral complications, and failure to undertake surgery when indicated according to ESC guidelines. Management by a multidisciplinary team and early, aggressive surgery are essential to improve outcomes.

Diagnosis of prosthetic valve endocarditis is frequently difficult and ESC guidelines recommend I8F-fluorodeoxyglucose (I8F-FDG) PET imaging in challenging cases. ${ }^{58}$ Amongst 173 patients with left-sided endocarditis, diagnosis using I8F-FDG PET/CT was associated with a significantly higher rate of the primary endpoint [death, recurrent endocarditis, HF, non-scheduled cardiovascular hospitalization, new embolic event; HR $2.7(I . I-6.7), P=0.04$ ] in those prosthetic valve infection, whilst moderate-intense valve uptake was associated with new embolic events [HR 7.5 (I.2-45.2), $\mathrm{P}=0.03]^{.9}$

\section{CONCLUSIONS}

Recent advances in the management of VHD achieved by open collaboration between cardiologists and car- diac surgeons have been remarkable. Ongoing innovation, a multidisciplinary Heart Team approach to the management of individual patients, and its delivery via a network of specialist valve centres ${ }^{60}$ will further transform the dismal prognosis associated with the condition. Worldwide extension of these advances to low- and middle-income countries (where VHD remains endemic) is the next urgent priority.

Conflict of interest: R.K.B.: proctor for Boston Scientific, consultant for Edwards Lifesciences and speakers fees and educational grants from Medtronic and Abbott. M.D.: none to declare. B.P.: speakers fees and educational grants from Edwards Lifesciences.

\section{References}

I. lung B, Delgado V, Rosenhek R, Price S, Prendergast B, Wendler O, De Bonis M, Tribouilloy C, Evangelista A, Bogachev-Prokophiev A Apor A, Ince H, Laroche C, Popescu BA, Piérard L, Haude M, Hindricks G, Ruschitzka F, Windecker S, Bax JJ, Maggioni A, Vahanian A; on behalf of the EORP VHD II Registry Investigators. Contemporary presentation and management of valvular heart disease in Europe: the EURObservational Research Programme Valvular Heart Disease II Registry. Circulation 2019; |40: I I56-I I69.

2. lung B, Baron G, Butchart EG, Delahaye F, Gohlke-Bärwolf C, Levang OW, Tornos P, Vanoverschelde JL, Vermeer F, Boersma E, Ravaud $P$, Vahanian A. A prospective survey of patients with valvular heart disease in Europe: the Euro Heart Survey on Valvular Heart Disease. Eur Heart J 2003;24:123I-1243.

3. Sacchi S, Dhutia NM, Shun-Shin MJ, Zolgharni M, Sutaria N, Francis DP, Cole GD. Doppler assessment of aortic stenosis: a 25-operator study demonstrating why reading the peak velocity is superior to velocity time integral. Eur Heart J Cardiovasc Imaging 2018;19:1380 1389.

4. Lancellotti P, Magne J, Dulgheru R, Clavel M-A, Donal E, Vannan MA, Chambers J, Rosenhek R, Habib G, Lloyd G, Nistri S, Garbi M, Marchetta S, Fattouch K, Coisne A, Montaigne D, Modine T, Davin L, Gach O, Radermecker M, Liu S, Gillam L, Rossi A, Galli E, llardi F, Tastet L, Capoulade R, Zilberszac R, Vollema EM, Delgado V, Cosyns B, Lafitte S, Bernard A, Pierard LA, Bax JJ, Pibarot P, Oury C. Outcomes of patients with asymptomatic aortic stenosis followed up in heart valve clinics. JAMA Cardiol 2018;3:1060-1068.

5. Baumgartner H, Falk V, Bax J, De Bonis M, Hamm C, Holm PJ, lung $B$, Lancellotti $P$, Lansac $E$, Rodriguez Mu noz D, Rosenhek R, Sjo" gren J, Tornos Mas P, Vahanian A, Walther T, Wendler O, Windecker S, Zamorano JL; ESC Scientific Document Group. 2017 ESC/ EACTS guidelines for the management of valvular heart disease. Eur Heart J 2017;38:2739-279I.

6. Pawade T, Sheth T, Guzzetti E, Dweck MR, Clavel MA. Why and how to measure aortic valve calcification in patients with aortic stenosis. JACC Cardiovasc Imaging 2019;12:1835-1848.

7. Pawade T, Clavel M-A, Tribouilloy C, Dreyfus J, Mathieu T, Tastet L, Renard C, Gun M, Jenkins WSA, Macron L, Sechrist JW, Lacomis JM, Nguyen V, Galian Gay L, Cue'llar Calabria H, Ntalas I, Cartlidge TRG, Prendergast B, Rajani R, Evangelista A, Cavalcante JL, Newby DE, Pibarot P, Messika Zeitoun D, Dweck MR. Computed tomography aortic valve calcium scoring in patients with aortic stenosis. Circ Cardiovasc Imaging 2018; I :e007|46.

8. Cartlidge TRG, Doris MK, Sellers SL, Pawade TA, White AC, Pessotto R, Kwiecinski J, Fletcher A, Alcaide C, Lucatelli C, Densem C, Rudd JHF, van Beek EJR, Tavares A, Virmani R, Berman D, Leipsic JA, Newby DE, Dweck MR. Detection and prediction of bioprosthetic aortic valve degeneration. J Am Coll Cardiol 2019;73:1 I07-III9. 
9. Kitkungvan D, Nabi F, Kim RJ, Bonow RO, Khan MA, Xu J, Little SH, Quinones MA, Lawrie GM, Zoghbi WA, Shah DJ. Myocardial fibrosis in patients with primary mitral regurgitation with and without prolapse. J Am Coll Cardiol 2018;72: 823-834.

10. Hiemstra YL, Tomsic A, van Wijngaarden SE, Palmen M, Klautz RJM, Bax JJ, Delgado V, Ajmone Marsan N. Prognostic value of global longitudinal strain and etiology after surgery for primary mitral regurgitation. JACC Cardiovasc Imaging 2019. pii: S1936-878X(19)30426-7.

II. Prihadi EA, Vollema EM, Ng ACT, Ajmone Marsan N, Bax Jj, Delgado V. Determinants and prognostic implications of left ventricular mechanical dispersion in aortic stenosis. Eur Heart J Cardiovas Imaging 2019;20:740-748.

12. Ilardi F, Marchetta S, Martinez C, Sprynger M, Ancion A, Manganaro R, Sugimoto T, Tsugu T, Postolache A, Piette C, Cicenia M, Esposito G, Galderisi M, Oury C, Dulgheru R, Lancellotti P. Impact of aortic stenosis on layer-specific longitudinal strain: relationship with symptoms and outcome. Eur Heart J Cardiovasc Imaging 2019; doi: 10.1093/ehjci/jez215.

13. Tastet L, Tribouilloy C, Maréchaux S, Vollema EM, Delgado V, Salaun E, Shen M, Capoulade R, Clavel M-A, Arsenault M, Bédard É, Bernier $M$, Beaudoin J, Narula J, Lancellotti $P$, Bax J], Généreux $P$, Pibarot $P$. Staging cardiac damage in patients with asymptomatic aortic valve stenosis. J Am Coll Cardiol 2019;74:550-563.

14. Treibel TA, López B, González A, Menacho K, Schofield RS, Ravassa S, Fontana M, White SK, DiSalvo C, Roberts N, Ashworth MT, DI'ez J, Moon JC. Reappraising myocardial fibrosis in severe aortic stenosis: an invasive and noninvasive study in 133 patients. Eur Heart J 2018;39:699-709.

I5. Everett RJ, Tastet L, Clavel M-A, Chin CWL, Capoulade R, Vassiliou VS, Kwiecinski J, Gomez M, van Beek EJR, White AC, Prasad SK, Larose E, Tuck C, Semple S, Newby DE, Pibarot P, Dweck MR. Progression of hypertrophy and myocardial fibrosis in aortic stenosis: a multicenter cardiac magnetic resonance study. Circ Cardiovasc Imaging 20 I8; I I:e00745।.

16. Musa TA, Treibel TA, Vassiliou VS, Captur G, Singh A, Chin C, Dobson LE, Pica S, Loudon M, Malley T, Rigolli M, Foley JRJ, Bijsterveld P, Law GR, Dweck MR, Myerson SG, McCann GP, Prasad SK, Moon JC, Greenwood JP. Myocardial scar and mortality in severe aortic stenosis: data from the BSCMR Valve Consortium. Circulation 2018;138: 1935-1947.

17. Larsson SC, Bäck M, Rees JMB, Mason AM, Burgess S. Body mass index and body composition in relation to 14 cardiovascular conditions in UK Biobank: a Mendelian randomization study. Eur Heart J 2019; doi:10.1093/eurheartj/ehz388.

18. Bouchareb R, Boulanger M-C, Tastet L, Mkannez G, Nsaibia MJ, Hadji F, Dahou A, Messadeq Y, Arsenault BJ, Pibarot P, Bosse' $Y$, Marette A, Mathieu P. Activated platelets promote an osteogenic programme and the progression of calcific aortic valve stenosis. Eur Heart J 2019;40:1362-1373.

19. Zheng KH, Tsimikas S, Pawade T, Kroon J, Jenkins WSA, Doris MK, White AC, Timmers NKLM, Hjortnaes J, Rogers MA, Aikawa E, Arsenault BJ, Witztum JL, Newby DE, Koschinsky ML, Fayad ZA, Stroes ESG, Boekholdt SM, Dweck MR. Lipoprotein(a) and oxidized phospholipids drive disease progression by aggravating calcification in aortic valve stenosis patients. J Am Coll Cardiol 2019;73: 21502162 .

20. Tsimikas S, Gordts P, Nora C, Yeang C, Witztum JL. Statin therapy increases lipoprotein (a) levels. Eur Heart J 2019. pii: ehz3I0. doi:I0.1093/eurhearti/ehz3 I0.

2I. Peeters F, Meex SJR, Dweck MR, Aikawa E, Crijns H, Schurgers LJ, Kietselaer B. Calcific aortic valve stenosis: hard disease in the heart: a biomolecular approach towards diagnosis and treatment. Eur Heart J 2018;39:2618-2624.

22. Vavilis G, Ba "ck M, Occhino G, Trevisan M, Bellocco R, Evans M, Lindholm B, Szummer K, Carrero JJ. Kidney dysfunction and the risk of developing aortic stenosis. J Am Coll Cardiol 2019;73:305-3I4.

23. Rodriguez-Gabella T, Catalá $P$, Mu noz-García AJ, Nombela-Franco L, Del Valle R, Gutiérrez E, Regueiro A, Jimenez-Diaz VA, Ribeiro HB, Rivero F, Fernandez-Diaz JA, Pibarot P, Alonso-Briales JH, Ti-
rado-Conte G, Moris C, Diez Del Hoyo F, Jiménez-Britez G, Zaderenko N, Alfonso F, Gómez I, Carrasco-Moraleja M, Rodés-Cabau J, San Román Calvar JA, Amat-Santos IJ. Renin-angiotensin system inhibition following transcatheter aortic valve replacement. J Am Coll Cardiol 20I 9;74:63I-64I.

24. Mack MJ, Leon MB, Thourani VH, Makkar R, Kodali SK, Russo M, Kapadia SR, Malaisrie SC, Cohen DJ, Pibarot P, Leipsic J, Hahn RT, Blanke P, Williams MR, McCabe JM, Brown DL, Babaliaros V, Goldman S, Szeto WY, Genereux P, Pershad A, Pocock SJ, Alu MC, Webb JG, Smith CR. Transcatheter aortic valve replacement with a balloonexpandable valve in low-risk patients. N Eng J Med 2019;380:16951705.

25. Popma JJ, Deeb GM, Yakubov SJ, Mumtaz M, Gada H, O'Hair D, Bajwa T, Heiser JC, Merhi W, Kleiman NS, Askew J, Sorajja P, Rovin J, Chetcuti SJ, Adams DH, Teirstein PS, Zorn GL, Forrest JK, Tchétché D, Resar J, Walton A, Piazza N, Ramlawi B, Robinson N, Petrossian G, Gleason TG, Oh JK, Boulware MJ, Qiao H, Mugglin AS, Reardon MJ. Transcatheter aortic valve replacement with a selfexpanding valve in low-risk patients. N Eng J Med 2019;380:1706-17I5.

26. Siontis GCM, Overtchouk P, Cahill TJ, Modine T, Prendergast B, Praz F, Pilgrim T, Petrinic T, Nikolakopoulou A, Salanti G, Søndergaard L, Verma S, Jüni $P$, Windecker $S$. Transcatheter aortic valve implantation vs. surgical aortic valve replacement for treatment of symptomatic severe aortic stenosis: an updated meta-analysis. Eur Heart J 2019;40:3|43-3153.

27. Bekeredjian R, Szabo G, Balaban Ü, Bleiziffer S, Bauer T, Ensminger S, Frerker C, Herrmann E, Beyersdorf F, Hamm C, Beckmann A, Möllmann H, Karck M, Katus HA, Walther T. Patients at low surgical risk as defined by the Society of Thoracic Surgeons Score undergoing isolated interventional or surgical aortic valve implantation: in-hospital data and I-year results from the German Aortic Valve Registry (GARY). Eur Heart J 2019;40: I323-1330.

28. Gleason TG, Reardon MJ, Popma JJ, Deeb GM, Yakubov SJ, Lee JS, Kleiman NS, Chetcuti S, Hermiller JB, Heiser J, Merhi W, Zorn GL, Tadros P, Robinson N, Petrossian G, Hughes GC, Harrison JK, Conte JV, Mumtaz M, Oh JK, Huang J, Adams DH; CoreValve U.S. Pivotal High Risk Trial Clinical Investigators. 5-year outcomes of selfexpanding transcatheter versus surgical aortic valve replacement in high-risk patients. J Am Coll Cardiol 2018;72:2687-2696.

29. Thyregod HGH, Ihlemann N, Jørgensen TH, Nissen H, Kjeldsen BJ, Petursson P, Chang Y, Franzen OW, Engstrøm T, Clemmensen $\mathrm{P}$, Hansen PB, Andersen LW, Steinbruüchel DA, Olsen PS, Søndergaard L. Five-year clinical and echocardiographic outcomes from the Nordic Aortic Valve Intervention (NOTION) randomized clinical trial in lower surgical risk patients. Circulation 2019;139: 27/42723.

30. Blackman DJ, Saraf S, MacCarthy PA, Myat A, Anderson SG, Malkin CJ, Cunnington MS, Somers K, Brennan P, Manoharan G, Parker J, Aldalati O, Brecker SJ, Dowling C, Hoole SP, Dorman S, Mullen M, Kennon S, Jerrum M, Chandrala P, Roberts DH, Tay J, Doshi SN, Ludman PF, Fairbairn TA, Crowe J, Levy RD, Banning AP, Ruparelia $\mathrm{N}$, Spence MS, Hildick-Smith D. Long-term durability of transcatheter aortic valve prostheses. J Am Coll Cardiol 2019;73: 537-545.

31. Søndergaard L, Ihlemann N, Capodanno D, Jørgensen TH, Nissen H, Kjeldsen BJ, Chang Y, Steinbrüchel DA, Olsen PS, Petronio AS, Thyregod HGH. Durability of transcatheter and surgical bioprosthetic aortic valves in patients at lower surgical risk. J Am Coll Cardiol 2019;73:546-553.

32. Vemulapalli S, Carroll JD, Mack MJ, Li Z, Dai D, Kosinski AS, Kumbhani DJ, Ruiz CE, Thourani VH, Hanzel G, Gleason TG, Herrmann $\mathrm{HC}$, Brindis RG, Bavaria JE. Procedural volume and outcomes for transcatheter aortic-valve replacement. N Engl J Med 2019;380: $254 \mid-2550$.

33. Seeger J, Kapadia SR, Kodali S, Linke A, Wöhrle J, Haussig S, Makkar R, Mehran R, Rottbauer W, Leon M. Rate of peri-procedural stroke observed with cerebral embolic protection during transcatheter aortic valve replacement: a patient-level propensity-matched analysis. Eur Heart ] 2019;40:1334-1340. 
34. Kapadia SR, Kodali S, Makkar R, Mehran R, Lazar RM, Zivadinov R, Dwyer MG, Jilaihawi $H$, Virmani R, Anwaruddin S, Thourani VH, Nazif T, Mangner N, Woitek F, Krishnaswamy A, Mick S, Chakravarty $T$, Nakamura M, McCabe JM, Satler L, Zajarias A, Szeto WY, Svensson L, Alu MC, White RM, Kraemer C, Parhizgar A, Leon MB, Linke A; SENTINEL Trial Investigators. Protection against cerebral embolism during transcatheter aortic valve replacement. J Am Coll Cardiol 2017;69: 367-377.

35. Haussig S, Mangner N, Dwyer MG, Lehmkuhl L, Lu" cke C, Woitek F, Holzhey DM, Mohr FW, Gutberlet M, Zivadinov R, Schuler G, Linke A, Effect of a cerebral protection device on brain lesions following transcatheter aortic valve implantation in patients with severe aortic stenosis: the CLEAN-TAVI randomized clinical trial. JAMA 20I6;316:592-60I.

36. Seeger J, Gonska B, Otto M, Rottbauer W, Wohrle J, Cerebral embolic protection during transcatheter aortic valve replacement significantly reduces death and stroke compared with unprotected procedures. JACC Cardiovasc Interv 2017; 10:2297-2303.

37. Lanz J, Kim WK, Walther T, Burgdorf C, Mo“Illmann H, Linke A, Redwood S, Thilo C, Hilker M, Joner M, Thiele H, Conzelmann L, Conradi L, Kerber S, Schymik G, Prendergast B, Husser O, Stortecky $S$, Heg D, Jüni P, Windecker S, Pilgrim T; SCOPE I investigators. Safety and efficacy of a self-expanding versus a balloon-expandable bioprosthesis for transcatheter aortic valve replacement in patients with symptomatic severe aortic stenosis: a randomised non-inferiority trial. Lancet 2019;394:1619-1628.

38. Allen KB, Chhatriwalla AK, Saxon JT, Cohen DJ, Nguyen TC, Webb J, Loyalka P, Bavry AA, Rovin JD, Whisenant B, Dvir D, Kennedy KF, Thourani V, Lee R; Bioprosthetic Valve Fracture Investigators. Bioprosthetic valve fracture: technical insights from a multicenter study. J Thorac Cardiovasc Surg 2019;158: 1317-1328.el.

39. Khan JM, Greenbaum AB, Babaliaros VC, Rogers T, Eng MH, Paone G, Leshnower BG, Reisman M, Satler L, Waksman R, Chen MY, Stine AM, Tian X, Dvir D, Lederman RJ. The BASILICA trial: prospective multicenter investigation of intentional leaflet laceration to prevent TAVR coronary obstruction. JACC Cardiovasc Interv 2019;12:1240-1252.

40. Stone GW, Lindenfeld J, Abraham WT, Kar S, Lim DS, Mishell JM, Whisenant B, Grayburn PA, Rinaldi M, Kapadia SR, Rajagopal V, Sarembock IJ, Brieke A, Marx SO, Cohen DJ, Weissman NJ, Mack Mj; for the COAPT Investigators. Transcatheter mitral-valve repair in patients with heart failure. N Engl J Med 20I8;379:2307-23I8.

4I. Obadia J-F, Messika-Zeitoun D, Leurent G, lung B, Bonnet G, Piriou $\mathrm{N}$, Lefèvre $T$, Piot $C$, Rouleau F, Carrié $D$, Nejjari M, Ohlmann $P$, Leclercq F, Saint Etienne C, Teiger E, Leroux L, Karam N, Michel N, Gilard M, Donal E, Trochu J-N, Cormier B, Armoiry X, Boutitie F, Maucort-Boulch D, Barnel C, Samson G, Guerin P, Vahanian A, Mewton N; for the MITRA-FR Investigators. Percutaneous repair or medical treatment for secondary mitral regurgitation. N Engl J Med 2018;379:2297-2306.

42. Praz F, Grasso C, Taramasso M, Baumbach A, Piazza N, Tamburino C, Windecker S, Maisano F, Prendergast B, Mitral regurgitation in heart failure: time for a rethink. Eur Heart J 2019;40:2 189-2193.

43. Nishimura RA, Otto CM, Bonow RO, Carabello BA, Erwin JP, Fleisher LA, Jneid H, Mack MJ, McLeod CJ, O'Gara PT, Rigolin VH, Sundt TM, Thompson A. 2017 AHA/ACC focused update of the 2014 AHA/ACC guideline for the management of patients with valvular heart disease: a report of the American College of Cardiology/ American Heart Association Task Force on Clinical Practice Guidelines. J Am Coll Cardiol 2017;70:252-289.

44. lung B, Armoiry X, Vahanian A, Boutitie F, Mewton N, Trochu JN, Lefèvre $T$, Messika-Zeitoun $D$, Guerin $P$, Cormier B, Brochet $E$, Thibault H, Himbert D, Thivolet S, Leurent G, Bonnet G, Donal E, Piriou N, Piot C, Habib G, Rouleau F, Carrié D, Nejjari M, Ohlmann P, Saint Etienne C, Leroux L, Gilard M, Samson G, Rioufol G, Maucort-Boulch D, Obadia JF; for the MITRA-FR Investigators. Percutaneous repair or medical treatment for secondary mitral regurgitation: outcomes at 2 years. Eur J Heart Fail 2019;doi:10.1002/ ejhf. 1616.
45. Mack MJ. COAPT: three-year outcomes from a randomized trial of transcatheter mitral valve leaflet approximation in patients with heart failure and secondary mitral regurgitation. Oral presentation at Transcatheter Cardiovascular Therapeutics (TCT) congress 2019; San Francisco. 2019.

46. Grayburn PA, Sannino A, Packer M, Proportionate and disproportionate functional mitral regurgitation: a new conceptual framework that reconciles the results of the MITRA-FR and COAPT trials. JACC Cardiovasc Imaging 2019;12: 353-362.

47. Baron SJ, Wang K, Arnold SV, Magnuson EA, Whisenant B, Brieke A, Rinaldi M, Asgar AW, Lindenfeld J, Abraham WT, Mack MJ, Stone GW, Cohen DJ; COAPT Investigators. Cost-effectiveness of transcatheter mitral valve repair versus medical therapy in patients with heart failure and secondary mitral regurgitation: results from the COAPT trial. Circulation 2019;140:188I-1891.

48. Witte KK, Lipiecki J, Siminiak T, Meredith IT, Malkin CJ, Goldberg SL, Stark MA, von Bardeleben RS, Cremer PC, Jaber WA, Celermajer DS, Kaye DM, Sievert $H$. The REDUCE FMR trial: a randomized sham-controlled study of percutaneous mitral annuloplasty in functional mitral regurgitation. JACC Heart Fail 2019;7: 945-955.

49. Avenatti E, Mackensen GB, El-Tallawi KC, Reisman M, Gruye L, Barker CM, Little SH, Diagnostic value of 3-dimensional vena contracta area for the quantification of residual mitral regurgitation after MitraClip procedure. JACC Cardiovasc Interv 2019;12:582-59|.

50. Petrus AHJ, Dekkers OM, Tops LF, Timmer E, Klautz RJM, Braun J, Impact of recurrent mitral regurgitation after mitral valve repair for functional mitral regurgitation: long-term analysis of competing outcomes. Eur Heart J 2019;40: 2206-22I4.

5I. Rodes-Cabau J, Hahn RT, Latib A, Laule M, Lauten A, Maisano F, Schofer J, Campelo-Parada F, Puri R, Vahanian A. Transcatheter therapies for treating tricuspid regurgitation. J Am Coll Cardiol 2016;67:1829-1845.

52. Braun D, Rommel K-P, Orban M, Karam N, Brinkmann I, Besler C, Massberg S, Nabauer M, Lurz P, Hausleiter J, Acute and short-term results of transcatheter edge-to-edge repair for severe tricuspid regurgitation using the MitraClip XTR system. JACC Cardiovasc Interv 2019;12:604-605.

53. Nickenig G, Weber M, Lurz P, von Bardeleben RS, Sitges M, Sorajja P, Hausleiter J, Denti P, Trochu JN, Na bauer M, Dahou A, Hahn RT. Transcatheter edge-toedge repair for reduction of tricuspid regurgitation: 6-month outcomes of the TRILUMINATE single-arm study. Lancet 20I9;394:2002-20II.

54. Taramasso M, Benfari G, van der Bijl P, Alessandrini H, AttingerToller A, Biasco L, Lurz P, Braun D, Brochet E, Connelly KA, de Bruijn S, Denti P, Deuschl F, Estevez-Loureiro R, Fam N, Frerker C, Gavazzoni M, Hausleiter JR, Ho E, Juliard JM, Kaple R, Besler C, Kodali S, Kreidel F, Kuck KH, Latib A, Lauten A, Monivas V, Mehr M, Muntane' -Carol G, Nazif T, Nickening G, Pedrazzini G, Philippon F, Pozzoli A, Praz F, Puri R, Rodés-Cabau J, Scha Fer U, Schofer J, Sievert H, Tang GHL, Thiele H, Topilsky Y, Rommel KP, Delgado V, Vahanian A, Von Bardeleben RS, Webb JG, Weber M, Windecker S, Winkel M, Zuber M, Leon MB, Hahn RT, Bax JJ, Enriquez-Sarano M, Maisano F. Transcatheter versus medical treatment of symptomatic severe tricuspid regurgitation. J Am Coll Cardiol 2019;doi: 10.1016/j. jacc.2019.09.028.

55. Nordmeyer J, Ewert P, Gewillig M, AlJufan M, Carminati M, Kretschmar O, Uebing A, Dähnert I, Röhle R, Schneider H, Witsenburg M, Benson L, Gitter R, Bökenkamp R, Mahadevan V, Berger F, Acute and midterm outcomes of the post-approval MELODY Registry: a multicentre registry of transcatheter pulmonary valve implantation. Eur Heart J 2019;40:2255-2264.

56. McElhinney DB, Sondergaard L, Armstrong AK, Bergersen L, Padera RF, Balzer DT, Lung T-H, Berger F, Zahn EM, Gray RG, Hellenbrand WE, Kreutzer J, Eicken A, Jones TK, Ewert P, Endocarditis after transcatheter pulmonary valve replacement. J Am Coll Cardiol 2018;72:2717-2728.

57. Habib G, Erba P, lung B, Donal E, Cosyns B, Laroche C, Popescu BA, Prendergast B, Tornos P, Sadeghpour A, Oliver L, Vaskelyte J], Sow R, Axler O, Maggioni AP, Lancellotti P; EURO-ENDO Investigators. Clinical presentation, aetiology and outcome of infective 
endocarditis. Results of the ESC-EORP EURO-ENDO (European Infective Endocarditis) registry: a prospective cohort study. Eur Heart 2019;40:3222-3232.

58. Habib G, Lancellotti P, Antunes MJ, Bongiorni MG, Casalta J-P, Del Zotti F, Dulgheru R, El Khoury G, Erba PA, lung B, Miro JM, Mulder BJ, Plonska-Gosciniak E, Price S, Roos-Hesselink J, Snygg-Martin U, Thuny F, Tornos Mas P, Vilacosta I, Zamorano JL; for the ESC Scientific Document Group. 2015 ESC guidelines for the management of infective endocarditis: the task force for the Management of Infective Endocarditis of the European Society of Cardiology (ESC). Eur Heart J 20I5;36:3075-3I 28.

59. San S, Ravis E, Tessonier L, Philip M, Cammilleri S, Lavagna F, Norscini G, Arregle F, Martel H, Oliver L, Torras O, Renard S, Ambrosi P, Camoin L, Casalta AC, Hubert S, Casalta JP, Gouriet F, Riberi A,
Avierinos J-F, Lepidi H, Collart F, Raoult D, Drancourt M, Habib G, Prognostic value of $18 \mathrm{~F}$-fluorodeoxyglucose positron emission tomography/computed tomography in infective endocarditis. J Am Coll Cardiol 2019;74:1031-1040.

60. Nishimura RA, O'Gara PT, Bavaria JE, Brindis RG, Carroll JD, Kavinsky CJ, Lindman BR, Linderbaum JA, Little SH, Mack MJ, Mauri L, Miranda WR, Shahian DM, Sundt TM 3rd. 2019 AATS/ACC/ASE/SCAI/ STS expert consensus systems of care document: a proposal to optimize care for patients with valvular heart disease: a joint report of the American Association for Thoracic Surgery, American College of Cardiology, American Society of Echocardiography, Society for Cardiovascular Angiography and Interventions, and Society of Thoracic Surgeons. J Am Coll Cardiol 2019;73:2609-2635. 